\title{
PENGARUH PEMBERIAN Trichoderma Sp UNTUK MENGENDALIKAN PENYAKIT LAYU FUSARIUM PADA BEBERAPA JENIS PISANG DI LAHAN YANG TELAH TERINFEKSI
}

\author{
BUKHARI ${ }^{1 *}$ DAN NURYULSEN SAFRIDAR ${ }^{1}$ \\ ${ }^{1}$ Prodi Agroteknologi Fakultas Pertanian Universitas Jabal Ghafur \\ Jl. Gle Gapui, Peutoe, Sigli, Kabupaten Pidie, Aceh 24182 \\ *E-mail:bukharimp@g mail.com
}

\begin{abstract}
The experimental design used was a $4 \times 4$ factorial with 2 replications in a randomized block design (RAK) pattern. The first factor is the Type of Banana $(J)$ consisting of 4 levels: $J_{l}$ (Raja Banana ), $J_{2}$ (Ambon Banana), $J_{3}$ (Barangan Banana) and $J_{4}$ (Geupok Banana). The second factor was the mixing of Trichoderma Sp with organic manure aplication (D) consisting of 4 levels: DO (without trichoderma sp), D1 (200 g trichoderma sp in $4 \mathrm{~kg}$ manure), D2 (200 gr trichoderma sp in $8 \mathrm{~kg}$ manure), and D3 (200 gr trichoderma sp in $12 \mathrm{~kg}$ manure). Observations made include: Intensity of Fusarium oxysporum wilting attack, number of leaves, Leaf length and stem diameeter. The results showed that the type of banana had a very significant effect on the intensity of fusarium oxysporum wilt disease and the number of leaves, but no significant effect on the length and diameter of the stem. Barangan Bananas and Ambon Bananas show stronger resilience (more resistant to fusarium oxysporum wilt disease). While the Raja Banana and Geupok Bananas look more sensitive to the attack of the disease. The mixing of Trichoderma Sp with organic manure also significantly influenced the intensity of fusarium oxysporum wilt disease, number of banana leaf and leaf length, but no significant effect on stem diameter. The best dose is found in treatment D1, but not different from D2. An increase in the amount of organic matter manure on Trichoderma sp dosage can decrease resistance to Fusarium oxysporum wilt disease.
\end{abstract}

Keywords: Trichoderma sp, Fusarium and Banana Wilt Diseases

Diterima: 2 Juni 2018, disetujui : 15 Juli 2018

\section{PENDAHULUAN}

Pisang (Musa paradisiaca. L) yang merupakan komoditas asli Indonesia dapat dijadikan salah satu andalan produk hortikultura yang diharapkan dapat bersaing dipasar Global dunia internasional.

Tanaman pisang diprioritaskan karena merupakan salah satu produk yang penting, baik sebagai bahan baku dalam industri makanan (olahan) maupun sebagai produk yang dikonsumsi dalam bentuk segar (buah meja) yang berpotensi untuk diekspor. Lingkungan yang strategis untuk pengembangan tanaman hortikultura, terutama untuk tanaman buah perlu ditelaah secara seksama sejalan dengan perubahan pertanian global. Kondisi tersebut menuntut produk tanaman buah harus memiliki daya saing tinggi. Oleh karena itu, pengembangan tanaman buah pada saat sekarang dan akan datang harus diarahkan kepada 
produk bermutu, efisien, ramah lingkungan, dan berkualitas tinggi (Supriyadi dan Satuhu, 2004).

Akhir-akhir ini hampir semua varietas pisang mengalami serangan penyakit layu Fusarium yang rata-rata mengakibatkan kematian dan penurunan produksi tanaman pisang, penyakit layu Fusarium Oxysporum yang berkembang begitu cepat dam mampu menginfeksi tanaman pisang sehingga mengakibatkan kerugian yang cukup besar bagi petani pisang. Jamur Fusarium Oxysporum menyerang jaringan batang melalui akar yang luka. Batang yang terserang mengering dan berubah warna menjadi kecoklatan, tepi daun menjadi kuning tua atau layu, tangkai daun patah dibagian pangkal. Kadang-kadang lapisan luar batang terbelah mulai dari permukaan tanah. Tanaman yang terserang tidak mampu berbuah atau buahnya tidak berisi (Semangun, 2004). Layu Fusarium pada tanaman telah dapat dikendalikan dengan Trichoderma spp. Trichoderma sp merupakan agen hayati antagonis yang dapat berperan menekan aktifitas patogen tumbuhan dari golongan jamur (Nurbalis dan Martinus, 2009 ;Purwantisari dan Rini, 2009). Hasil penelitian Shofiyani dan Aman Suryadi (2014) ternyata penggunaan agensia hayati Trichoderma Viridae dengan dosis $40 \mathrm{~g} /$ lubang dapat mengendalikan penyakit layu pada tanaman bawang merah.

Agen antagonis patogen tumbuhan adalah mikroorganisme yang mengintervensi aktivitas patogen dalam menimbulkan penyakit (Hajieghuanri. et. al, 2008), agen tersebut tidak dapat mengejar inang yang telah masuk kedalam jaringan tanaman, efektivitasnya dapat dilihat dengan tidak berkembangnya penyakit tersebut (Soesanto et al., 2008; Nurbalis dan
Martinus, 2011) . Proses antagonis Trichoderma sp terhadap patogen tular tanah bekerja dengan cara parasitisme, kompetensi dan antibiosis ( Widdyawati et. al, 1998; Purwantisari dan Rini, 2009). Trichoderma secara umum digunakan sebagai agen biokontrol untuk melawan jamur phytopatogen dan beberapa strain diantaranya dapat memproduksi antibiotik, memparasit jamur lain, antagonistic terhadap banyak patogen tanaman dan bersaing dengan mikroorganisme pengganggu tanaman (Harman, 2000; Weavor et. al, 2005). Aktifitas agen biokontrol juga dipengaruhi oleh hadirnya nutrient organik dalam tanah (Harman, 2000). Hasil penelitian Nurbalis dan Martinus (2011) bahan organik beras dan ampas tebu telah dapat meningkatkan kepadatan Trichoderma Viridae pada tanaman pisang.

Banyak jenis pisang dan bahan rganik yang ada didaerah centra produksi pisang tersebut, namun varietas mana yang dapat berinteraksi dengan agen hayati Trichoderma spp ketika dicampur dengan pupuk kandang untuk menekan serangan penyakit layu Fusarium merupakan persoalan menarik untuk diteliti. Penelitian ini bertujuan untuk mengetahui perbedaan pengaruh diantara jenis pisang yang ditanam pada lahan petani yang telah terinfeksi. terhadap serangan penyakit layu fusarium, pengaruh aplikasi agen hayati trichoderma sp dapat mengendalikan penyakit layu fusarium oxysporum pada tanaman pisang (Musa sapientum L.), dan mendapatkan jenis pisang yang mamput berinteraksi dengan agen hayati campuran Trichoderma sp dengan bahan organik dalam menekan serangan penyakit layu fusarium. 


\section{METODE PENELITIAN}

\section{Tempat dan Waktu Penelitian}

Penelitian ini telah dilaksanakan di kebun petani yang sudah terkontaminasi penyakit Layu Fusarium di desa Dayah kecamatan Keumala kabupaten Pidie, yang berlangsung dari bulan Mei 2016 sampai Agustus 2016.

\section{Bahan dan Alat}

Bahan-bahan digunakan dalam penelitian ini adalah bibit pisang yang telah berumur 4 bulan dari hasil penelitian tahun pertama yang pertmbuhannya lebih baik dan seragam dengan tinggi rata-rata $2 \mathrm{~m}$ dan bibit pisang yang lain dengan ukuran fisik yang sama, pupuk kandang Trichoderma $\mathrm{sp}$, bakteri pseudomonas fluorescens, serta bahan-bahan pendukung lainnya yang diperlukan seperti kawat beronjong.

Alat yang digunakan dalam penelitian ini adalah parang, cangkul, pisau, garu, timba, gembor (alat penyiraman), tali, timbangan, alat tulismenulis dan alat-alat lain yang diperlukan dalam penelitian

\section{Rancangan Penelitian}

Penelitian ini menggunakan Rancangan Acak Kelompok (RAK) pola faktorial yang terdiri dari dua faktor yaitu: faktor jenis pisang (J) terdiri dari 4 taraf dan pemberian Campuran Trichoderma sp (D) terdiri dari 4 taraf yaitu.

Faktor Jenis Pisang (J), terdiri dari 4 taraf, yaitu:

$$
\begin{aligned}
& \mathrm{J}_{1}=\text { Pisang Raja } \\
& \mathrm{J}_{2}=\text { Pisang Ambon } \\
& \mathrm{J}_{3}=\text { Pisang Baarangan } \\
& \mathrm{J}_{4}=\text { Pisang Geupok }
\end{aligned}
$$

Faktor Pemberian Campuran Trichoderma Sp (D), terdiri dari 4 taraf, yaitu:

$\mathrm{D}_{0}=$ Tanpa bampuran trichoderma $s p$ (Kontrol).
$\mathrm{D}_{1}=200$ gr Trichoderma dalam $4 \mathrm{~kg}$

Pupuk Kandang

$\mathrm{D}_{2}=200$ gr Trichoderma dalam $8 \mathrm{~kg}$ Pupuk Kandang

$\mathrm{D}_{3}=200$ gr Trichoderma dalam $12 \mathrm{~kg}$ Pupuk Kandang

Dengan demikian terdapat 16 kombinasi perlakuan dengan 2 ulangan sehingga diperoleh 32 satuan percobaan. Tiap satuan percobaan terdiri dari 2 tanaman sampel dengan susunan kombinasi perlakuan tertera pada tabel 1 .

$$
\text { Model matematika untuk }
$$

Rancangan Acak Kelompok (RAK) pola faktorial (Hanafiah, 2000) sebagai linearaditif berikut :
Yijk $=\mu+\mathbf{K k}+\mathbf{J i}+\mathbf{D j}+$ (JD)ij $+\varepsilon \mathbf{i j k}$

Yijk = Nilai pengamatan pada kelompok percobaan ke-k yang memperoleh kombinasi perlakuan ij (taraf ke-i dari faktor jenis pisang dan taraf ke- $\mathrm{j}$ dari faktor pemberian Trichoderma Sp)

$. \mu=$ Nilai rata-rata tengah.

$\mathrm{Kk}=$ Nilai pengamatan pengaruh kelompok ke-k.

$\mathrm{Ji}=$ Nilai pengamatan pengaruh jenis pisang pada taraf ke-i.

$\mathrm{Dj} \quad=$ Nilai pengamatan pengaruh pemberian Trichoderma sp pada taraf ke-j.

$(\mathrm{JD}) \mathrm{ij}=$ Nilai pengamatan interaksi jenis pisang pada taraf ke- $\mathrm{i}$ dan pemberian Trichoderma Sp pada taraf ke-j.

$\varepsilon \mathrm{ijk}=$ Pengaruh acak percobaan pada kelompok percobaan ke-k yang memperoleh kombinasi perlakuan jenis pisang pada taraf ke-i dan pemberian Trichoderma sp pada taraf kej. 
Tabel 1. Susunan Kombinasi Perlakuan Yang Dicobakan

\begin{tabular}{|c|c|c|}
\hline$\underline{\text { Perlakuan }}$ & $\underline{\text { Jenis Pisang }}$ & $\frac{\text { Pemberian Trichoderma sp (g) }}{\text { Dan pupuk kandang (kg) }}$ \\
\hline & & Kontrol \\
\hline $\mathrm{J}_{1} \mathrm{D}_{0}$ & Raja & $200 \mathrm{~g}$ dalam $4 \mathrm{~kg}$ pupuk kandang \\
\hline $\mathrm{J}_{1} \mathrm{D}_{1}$ & Raja & $200 \mathrm{~g}$ dalam $8 \mathrm{~kg}$ pupuk kandang \\
\hline $\begin{array}{lll}\mathrm{J}_{1} & \mathrm{D}_{2}\end{array}$ & Raja & $200 \mathrm{~g}$ dalam $12 \mathrm{~kg}$ pupuk kandang \\
\hline $\mathrm{J} 1 \mathrm{D}_{3}$ & Raja & \\
\hline $\mathrm{J}_{1} \mathrm{D}_{0}$ & Raja & Kontrol \\
\hline $\mathrm{J}_{1} \mathrm{D}_{1}$ & Raja & $200 \mathrm{~g}$ dalam $4 \mathrm{~kg}$ pupuk kandang \\
\hline $\mathrm{J}_{1} \mathrm{D}_{2}$ & Raja & $200 \mathrm{~g}$ dalam $8 \mathrm{~kg}$ pupuk kandang \\
\hline $\mathrm{J} 1 \mathrm{D}_{3}$ & Raja & $200 \mathrm{~g}$ dalam $12 \mathrm{~kg}$ pupuk kandang \\
\hline $\mathrm{J}_{2} \mathrm{D}_{0}$ & Ambon & Kontrol \\
\hline $\mathrm{J}_{2} \mathrm{D}_{1}$ & Ambon & $200 \mathrm{~g}$ dalam $4 \mathrm{~kg}$ pupuk kandang \\
\hline $\mathrm{J}_{2} \mathrm{D}_{2}$ & Ambon & $200 \mathrm{~g}$ dalam $8 \mathrm{~kg}$ pupuk kandang \\
\hline $\mathrm{J}_{2} \mathrm{D}_{3}$ & Ambon & $200 \mathrm{~g}$ dalam $12 \mathrm{~kg}$ pupuk kandang \\
\hline $\mathrm{J}_{3} \mathrm{D}_{0}$ & Barangan & Kontrol \\
\hline $\mathrm{J}_{3} \mathrm{D}_{1}$ & Barangan & $200 \mathrm{~g}$ dalam $4 \mathrm{~kg}$ pupuk kandang \\
\hline $\mathrm{J}_{3} \mathrm{D}_{2}$ & Barangan & $200 \mathrm{~g}$ dalam $8 \mathrm{~kg}$ pupuk kandang \\
\hline $\mathrm{J}_{3} \mathrm{D}_{3}$ & Barangan & $200 \mathrm{~g}$ dalam $12 \mathrm{~kg}$ pupuk kandang \\
\hline $\mathrm{J}_{4} \mathrm{D}_{0}$ & Geupok & Kontrol \\
\hline $\mathrm{J}_{4} \mathrm{D}_{1}$ & Geupok & $200 \mathrm{~g}$ dalam $4 \mathrm{~kg}$ pupuk kandang \\
\hline $\mathrm{J}_{4} \mathrm{D}_{2}$ & Geupok & $200 \mathrm{~g}$ dalam $8 \mathrm{~kg}$ pupuk kandang \\
\hline $\mathrm{J}_{4} \mathrm{D}_{3}$ & Geupok & $200 \mathrm{~g}$ dalam $12 \mathrm{~kg}$ pupuk kandang \\
\hline
\end{tabular}

\section{Pelaksanaan penelitian}

\section{Persiapan Lahan dan Lobang Tanam}

Persiapan lahan areal penanaman pisang terutama dilakukan terhadap gulma yang menyebabkan peningkatan kelembaban lahan. Pembersihan juga dilakukan terhadap tanaman keras yang dapat menghambat peneltrasi sinar matahari. Lahan yang sudah dibersihkan kemudian dicangkul dengan kedalaman $30 \mathrm{~cm}$ agar struktur tanah menjadi lebih gembur sehingga dapat memperbaiki aerasi tanah dan memudahkan tanaman pisang dalam mengambil unsur hara. Pemasangan ajir dilakukan untuk menandai lubang tanam sesuai dengan satuan jarak tanam yaitu 2,5 × 2,5 meter. Lubang tanam dibuat dengan ukuran $50 \mathrm{x}$ $50 \mathrm{~cm}$ serta kedalamannya $50 \mathrm{~cm}$ sehingga memerlukan lahan seluas 200 $\mathrm{m}^{2}$.

\section{Persiapan Bibit Pisang}

Bibit pisang yang siap ditanam diperoleh dari hasil penelitian terdahulu dijadikan sebagai sumber bibit pada penelitian tahun ini sebagai penelitian lanjutan. Untuk mencukupi tanaman sampel bibit tanaman diambil dari tanaman induk dikebun petani dengan ukuran dan jenis bibit yang sama. Bibit yang berasal dari hasil penelitian tahun pertama ditanam dalam kelompok I dan yang berasal dari kebun petani ditanam dalam kelompok II.

\section{Penyiapan Agens antagonis} Trichoderma sp.

Agens antagonis Trichoderma sp yang telah dikembangkan pada media beras sebanyak $1 \mathrm{~kg}$ dicampur dengan 40 $\mathrm{kg}$ pupuk kandang. Proses pecampuran dimulai dengan meratakan pupuk kandang setebal $10 \mathrm{~cm}$, kemudian ditaburkan Trichoderma sp secara merata diatasnya, pr.oses ini dilakukan berulang 
sehingga membentuk suatu lapisan hingga kedua bahan tersebut habis. Selanjutnya ketika proses pencampuran media telah siap lalu disiram dengan air sampai agak lembab dan ditutup dengan dedaunan supaya tetap lembab. Setelah 3 hari media diaduk sampai rata dan ditutup kembali., Trichoderma sp sudah siap diaplikasikan ke dalam lubang tanam sesuai dengan perlakuan pada setiap satuan percobaan satu minggu kemudian.

\section{Penanaman dan Aplikasi Trichoderma sp}

Sebelum dilakukan penanaman bibit pisang dari hasil penelitian tahun pertama dikeluarkan dari polibag dan yang berasal dari kebun petani direndam dalam larutan bakteri Pseudomonas fluorescens selama 20 menit dan untuk selanjutnya dimasukkan kedalam lubang tanam yang sudah tersedia. Penggunaan larutan bakteri pseudomonas fluorescens (pf) bertujuan untuk mencegah perkembangan bakteri penyebab layu bakteri pada tanaman pisang yang dikhawatirkan dapat mengaburkan hasil penelitian ini karena sama-sama meyebabkan penyakit layu. Konsentrasi larutan pf dibuat dengan cara melarutkan $250 \mathrm{ml}$ larutan bakteri ke dalam 10 liter air. Trichoderma diaplikasikan pada lubang tanam dengan cara menabur pada tiap lubang tanam, sehingga trichoderma akan langsung berasosiasi dengan perakaran tanaman.

\section{Pemupukan}

Pemupukan dilakukan dengan membuat larikan melingkar disekeliling batang tanaman dengan dosis $250 \mathrm{~g}$ Urea , 250 gr SP 36/lobang tanam dan 300 gr KCL ntuk setiap lubang tanam,

\section{Pemeliharaan}

\begin{tabular}{ll}
\multicolumn{2}{c}{ Pemeliharaan meliputi } \\
$\begin{array}{l}\text { penyiraman, } \\
\text { pengendalian }\end{array}$ hamaiangan & dan \\
henyakit.
\end{tabular}

Penyiraman dilakukan disekeliling lobang tanam yang disesuaikan dengan keadaan cuaca dilapangan. Tanaman pengganggu (gulma) yang tumbuh di lahan percobaan dibersihkan agar tanaman dapat tumbuh dengan optimal dan mengurangi kompetisi unsur hara antar tanaman pisang dengan gulma. Pembersihan dilakukan dengan menggunakan cangkul, parang dan sabit. Tanaman yang sehat diperoleh melalui pembiakan yang baik maka perlu dilakukan pencegahan serangan hama, pencegahan ini dilakukan dengan terus melakukan pengamatan perkembangan tanaman dan melihat keberadaan hama pada populasi tanaman. Karena pada penelitian ini mengamati intensitas serangan penyakit layu fusarium oxysporum, maka pengendalian hama dilakukan dengan cara fisik dan memiliki tanaman tidak terkontaminasi dengan bahan kimia yang dikhawatirkan berpengaruh dengan perkembangan Trichoderma sp.

\section{Pengamatan}

Parameter yang diamati dalam penelitian ini adalah :

Intensitas Serangan Penyakit Layu Fusarium oxysporum: Pengamatan intensitas serangan dilakukan 30, 60, 90 hari setelah tanam. Pengamatan dilakukan dengan cara mengamati helaian daun tanaman pisang pada setiap tanaman sampel dan menghitung tingkat serangan penyakit Ousarium oxyporum menggunakan rumus kerusakan mutlak Unterstenhofer (1963). Rumus tersebut adalah:

$$
. I=\frac{a}{a \times b} \times 100 \% \ldots \ldots(1)
$$

Keterangan :

I : Intensitas serangan

a : banyaknya contoh (daun, pucuk, bunga, buah, batang) yang rusak mutlak atau dianggap rusak mutlak. 
b : banyaknya contoh yang tidak rusak atau tidak menunjukkan gejala serangan kategori untuk jenis penyakit adalah sebagai berikut :

- Serangan ringan bila derajat serangan $0-25 \%$

- Serangan sedang bila derajat serangan $>25-<75 \%$

- Puso bila derajat serangan $>75 \%$

\section{Jumlah Daun (Helai)}

Pengamatan terhadap jumlah daun dilakukan pada umur 30, 60, dan 90 hari setelah tanam (HST). Dihitung secara manual, dari daun pertama sampai dengan

\section{HASIL DAN PEMBAHASAN Intensitas Serangan}

Hasil analisis ragam (Uji F) ternyata bahwa jenis pisang berpengaruh sangat nyata terhadap intensitas serangan penyakit layu fusarium oxysporum pada umur 90 HST dan berpengaruh nyata pada umur 30 dan 60 HST. Rata-rata intensitas serangan penyakit layu fusarium oxysporum umur 30,60 dan 90 HST akibat perbedaan jenis pisang dapat dilihat pada Tabel 2 berikut.

Dari Tabel 2 dapat dijelaskan bahwa, rata-rata intensitas serangan penyakit layu fusarium $s p$ umur 30 HST terberat akibat perbedaan jenis pisang dijumpai pada perlakuan $\mathrm{J}_{4}$ (pisang geupok) dengan nilainya 2.00, yang daun yang paling ujung, satuannya adalah helai.

\section{Panjang Daun (m)}

Pengamatan terhadap panjang daun dilakukan pada umur 30,60, dan 90 hari setelah tanam (HST).diukur secara manual, dari pangkal helaian daun sampai ujung daun, pengukuran dilakukan pada daun yang paling panjang.

\section{Diameter Batang $(\mathbf{C m})$}

Pengamatan terhadap diameter batang dilakukan pada umur 30, 60, dan 90 hari setelah tanam (HST). diukur secara manual, dari leher akar sampai pada ketinggian $30 \mathrm{~cm}$.

berbeda nyata dengan perlakuan $\mathrm{J}_{3}$ (pisang Barangan), $J_{2}$ (pisang ambon) dan $\mathrm{J}_{1}$ (pisang Raja). Pada umur 60 HST rata-rata intensitas serangan penyakit layu fusarium pada perlakuan $\mathrm{J}_{4}$ (pisang ge upok) sama beratnya dengan $\mathrm{J}_{1}$ (pisang Raja) dengan nilainya 2.50, yang berbeda nyata dengan perlakuan $\mathrm{J}_{2}$ (pisang ambon) dengan nilai 2.25 dan $\mathrm{J}_{3}$ (pisang Barangan) dengan nilai 2.00 . Sedangkan pada umur 90 HST rata-rata intensitas serangan terberat dijumpai pada perlakuan $\mathrm{J}_{4}$ (pisang geupok) dengan nilai 5.25 yang berbeda nyata dengan $J_{1}$ (pisang Raja) dengan nilai 4.13, $\mathrm{J}_{2}$ (pisang ambon) dan $\mathrm{J}_{3}$ (pisang Barangan) dengan nilai 3.63.

Tabel 2. Rata-rata Intesitas Serangan Penyakit Layu Fusarium Sp Umur 30, 60 dan 90 HST Akibat Perbedaan Jenis Pisang

\begin{tabular}{lccc}
\hline \multirow{2}{*}{ Jenis Pisang $(\mathrm{J})$} & \multicolumn{3}{c}{ Intensitas Serangan } \\
\cline { 2 - 4 } & $30 \mathrm{HST}$ & $60 \mathrm{HST}$ & $90 \mathrm{HST}$ \\
\hline Pisang Raja & $1.63 \mathrm{~b}$ & $2.50 \mathrm{c}$ & $4.13 \mathrm{~b}$ \\
Pisang Ambon & $1.75 \mathrm{~b}$ & $2.25 \mathrm{~b}$ & $3.63 \mathrm{a}$ \\
Pisang Barangan & $1.50 \mathrm{a}$ & $2.00 \mathrm{a}$ & $3.63 \mathrm{a}$ \\
Pisang Geupok & $2.00 \mathrm{c}$ & $2.50 \mathrm{c}$ & $5.25 \mathrm{c}$ \\
\hline \multicolumn{1}{c}{ BNJ 0,05} & 0.07 & 0.08 & 0.16 \\
\hline
\end{tabular}

Keterangan : Angka yang diikuti oleh huruf yang sama pada kolom yang sama berbeda tidak nyata pada taraf $\alpha=5 \%$ (Uji BNJ) 
Dari tabel di atas terlihat bahwa dari semua umur pengamatan ternyata pisang barangan merupakan jenis yang paling tahan terhadap serangan Penyakit layu fusarium yang dikuti oleh pisang ambon dan pisang raja serta pisang geupok. Namun pisang geupok merupakan jenis yang paling rentan terhadap serangan penyakit layu Fusarium dibandingkan dengan ketiga jenis lainnya. Secara keseluruhan seperti yang terlihat di lapangan (lahan penelitian) jika tanaman pisang sudah terserang, jamur fusarium tersebut terus masuk kedalam jaringan pembuluh sehingga sangat sulit dikendalikan, jamur fusarium mudah berpindah dari satu jaringan kejaringan lainnya dan cepat menyebar dari tanaman satu ke tanaman lainnya melalui perakaran yang luka. Swastika (2014) menyatakan bahwa pada umumnya penyebaran penyakit pada tanaman pisang adalah melalui bagian tanaman yang luka terutama akar. Selanjutnya Nazir (2000) berpedpat bahwa penyebaran jamur fusarium oxysporum bisa melalui air, manusia dan melalui bagian tanaman terinfeksi. Selajutnya Nazir juga menjelaskan bahwa kerentanan pisang terhadap serangan penyakit dipengaruhi oleh cara pembiakan tanaman pisang, dimana pisang umumnya dibiakkan secara vegetatif. Perbanyakan secara vegetatif membuat pisang amat mudah terkena serangan pengganggu, karena sempitnya keragaman genetik. Oleh karena itu suatu perkebunan yang terkena penyakit dapat menularkan dengan cepat ke perkebunan tetangganya sehingga seluruh kebun pisang dalam satu wilayah terjangkit penyakit layu fusarium.

Dari hasil penelitian ini terlihat bahwa ada perbedaan kemampuan ketahanan terhadap penyakit layu diantara jenis pisang yang dicobakan, pisang barangan mepakan jenis yang paling mampu bertahan yang dikuti oleh jenis pisang ambon dan pisang raja, pisang geupok merupaakan jenis yang paling peka terhadap serangan penyakit layu fusarium.

Hasil analisis ragam (Uji F) menunjukkan bahwa, pemberian campuran Trichoderma $S p$ dengan berpengaruh sangat nyata terhadap intensitas serangan penyakit layu fusarium oxysporum umur 30 , 60 dan 90 HST. Rata-rata intensitas serangan penyakit layu fusarium oxysporum umur 30, 60 dan 90 HST akibat pemberian campuran Trichoderma $S p$ dan bahan organik disajikan pada Tabel 4 berikut.

Tabel 3. Rata-rata Intensitas Serangan Penyakit Layu Fusarium Oxysporum Umur 30, 60 dan 90 HST Akibat Pemberian Trichoderma Sp

\begin{tabular}{lcccc}
\hline \multirow{2}{*}{ Trichoderma Sp (D) } & \multicolumn{3}{c}{ Intensitas Serangan (\%) } \\
\cline { 2 - 4 } & $30 \mathrm{HST}$ & 60 & $\mathrm{HST}$ & $90 \mathrm{HST}$ \\
\hline Tanpa trichoderma sp & $2.25 \mathrm{~d}$ & $3.75 \mathrm{~d}$ & $4.13 \mathrm{bc}$ \\
200 g trichoderma dalam 4 kg pukan & $1.00 \mathrm{a}$ & $1.33 \mathrm{a}$ & $3.18 \mathrm{a}$ \\
200 g trichoderma dalam 8 kg pukan & $1.75 \mathrm{~b}$ & $1.88 \mathrm{~b}$ & $3.88 \mathrm{~b}$ \\
200 g trichoderma dalam 12 kg pukan & $1.88 \mathrm{c}$ & $2.00 \mathrm{c}$ & $4.10 \mathrm{bc}$ \\
\hline BNJ 0,05 & 0.10 & 0.11 & 0,36 \\
\hline
\end{tabular}

Keterangan : Angka yang diikuti oleh huruf yang sama pada kolom yang sama berbeda tidak nyata pada taraf $\alpha=5 \%(\mathrm{Uji} B N J)$ 
Tabel 4. Rata-rata Jumlah Daun Pisang Umur 30, 60 dan 90 HST Akibat Perbedaan Jenis Pisang

\begin{tabular}{lccc}
\hline \multirow{2}{*}{ Jenis Pisang $(J)$} & \multicolumn{4}{c}{ Jumlah Daun (Helai) } \\
\cline { 2 - 4 } & $30 \mathrm{HST}$ & $60 \mathrm{HST}$ & $90 \mathrm{HST}$ \\
\hline Pisang Raja & $5.25 \mathrm{~b}$ & $5,75 \mathrm{a}$ & $8.63 \mathrm{~b}$ \\
Pisang Ambon & $5.88 \mathrm{c}$ & $6.55 \mathrm{~b}$ & $8.13 \mathrm{~b}$ \\
Pisang Barangan & $5.88 \mathrm{c}$ & $6,63 \mathrm{~b}$ & $9.25 \mathrm{c}$ \\
Pisang Geupok & $5.00 \mathrm{a}$ & $5.75 \mathrm{a}$ & $7.38 \mathrm{a}$ \\
\hline \multicolumn{1}{c}{ BNJ 0,05 } & 0.17 & 0,53 & 0,67 \\
\hline
\end{tabular}

Keterangan : Angka yang diikuti oleh huruf yang sama pada kolom yang sama berbeda tidak nyata pada $\operatorname{taraf} \alpha=5 \%(\mathrm{Uji} \mathrm{BNJ})$

Dari Tabel 3 dapat dijelaskan bahwa, rata-rata jumlah daun pisang terbanyak dijumpai pada perlakuan $\mathbf{J}_{3}$ dengan nilainya $5.88: 6,63$ dan 9,25 yang berbeda nyata dengan perlakuan semua jenis lainnya, kecuali dengan $\mathrm{J}_{2}$ dengan pada umur 60 HST. Hal ini telah memperjelas bahwa ada perbedaan ketahanan terhadap serangan penyakit layu fusarium diantara jenis pisang yang dicobakan. Jika kita lihat penampialn secara visua 1 keempat jenis pisang yang dicobakan di lahan petani yang telah terinfeksi, memang pisang barangan dan pisang ambon terlihat tumbuh lebih jagur dibandingkan dengan kedua jenis lainnya yaitu pisang raja dan pisang geupok, Sebelum penyakit layu fusarium terjangkit di daerah kabupaten Pidie, peneliti pernah mengamati secara visual keempat jenis pisang yang dicobakan ini mempunyai perawakan yang hampir sama. Keempat jenis pisang itu mempunyai batang dan tangkai daun yang besar, helaian yang panjang dan lebar, tetapi ketika mendapat serangan layu fusarium pisang barangan dan ambon yang terlihat lebih tahan, sedang

Tabel 5. Rata-rata Jumlah Daun Pisang Umur 30, 60 dan 90 HST akibat Pemberian campuran Trichoderma Sp dengan bahan organik pupuk kandang.

\begin{tabular}{lccc}
\hline \multirow{2}{*}{ Pemberian Trichoderma Sp (D) } & \multicolumn{3}{c}{ Jumlah Daun (Helai) } \\
\cline { 2 - 4 } & $30 \mathrm{HST}$ & $60 \mathrm{HST}$ & $90 \mathrm{HST}$ \\
\hline Tanpa trichoderma sp & $4.50 \mathrm{a}$ & $5.25 \mathrm{a}$ & $7.31 \mathrm{a}$ \\
200 g trichoderma dalam 4 kg pukan & $5.88 \mathrm{c}$ & $6.13 \mathrm{~b}$ & $9.50 \mathrm{~b}$ \\
200 g trichoderma dalam 8 kg pukan & $6.25 \mathrm{~d}$ & $6.75 \mathrm{~b}$ & $9.13 \mathrm{~b}$ \\
200 g trichoderma dalam 12 kg pukan & $5.38 \mathrm{~b}$ & $5.63 \mathrm{a}$ & $7.38 \mathrm{a}$ \\
\hline BNJ 0,05 & 0.24 & 0.43 & 0.52 \\
\hline
\end{tabular}

Keterangan : Angka yang diikuti oleh huruf yang sama pada kolom yang sama berbeda tidak nyata pada taraf $\alpha=5 \%(\mathrm{Uji} \mathrm{BNJ})$

Jurnal Ilmiah Pertanian Volume 15, No. 1, Agustus , 2018 
Spesies Trichoderma sp. disamping sebagai organisme pengurai, dapat pula berfungsi sebagai agens hayati. Trichoderma sp. dalam peranannya sebagai agens hayati bekerja berdasarkan mekanisme antagonis yang dimilikinya. Purwantisari dan Rini (2009), mengatakan bahwa Trichoderma sp. merupakan cendawan parasit yang dapat menyerang dan mengambil nutrisi dari cendawan lain. Biakan jamur Trichoderma dalam media aplikatif seperti dedak dapat diberikan ke areal pertanaman dan berlaku sebagai biodekomposer, mendekomposisi limbah organik (rontokan dedaunan dan ranting tua) menjadi kompos yang bermutu serta dapat berlaku sebagai biofungisida. Trichoderma $S p$ dapat menghambat pertumbuhan beberapa jamur penyebab penyakit pada tanaman antara lain Rigidiforus lignosus, Fusarium oxysporum, Rizoctonia solani, dan Sclerotium rolfsii.

\section{Panjang Daun}

Dari hasil sidik ragam ternyata jenis pisang tiak berpengaruh terhadap panjang daun, dimana daun pisang baik pada umur 30, 60 dan 90 hari tidak terlihat perbedaan panjang daun keempat jenis pisang memeperlihatkan panjang daun yang hampir sama, dari sini terbukti bahwa karakter panjang daun kempat jenis pisang adalah sama sehingga keempat jenis pisang memperlihakan rata-rata panjang daun yang tidak berbeda.

Hasil Analisis Ragam (Uji F) menunjukkan bahwa pemberian campuran trichoderma $s p$ dengan baahan organik berupa pupuk kandang berpengaruh sangat nyata terhadap panjang daun pada umur 30, 60 dan 90 hari. Selanjutnya pengujian perbedaan dosis campuran Trichoderma $s p$ dengan bahan organik menggunakan uji BNJ pada taraf $5 \%$ terhadap rata-rata panjang daun pisang umur 30, 60 dan 90 hari disajikan pada Tabel 6 .

Tabel 6. Rata-rata Panjang Daun Bibit pisang Umur 40, 80 dan 120 Hari Akibat Perbedaan Dosis Trichoderma $\mathrm{sp}$

\begin{tabular}{|c|c|c|c|}
\hline \multirow{2}{*}{ Dosis Trichoderma $\mathrm{sp}$} & \multicolumn{3}{|c|}{ Panjang Daun (m) Umur (hari) } \\
\hline & 30 HST & 60 HST & $90 \mathrm{HST}$ \\
\hline Tanpa trichoderma $\mathrm{sp}$ & 1,12 a & 2,16 a & 2,85 a \\
\hline $200 \mathrm{~g}$ trichoderma dalam $4 \mathrm{~kg}$ pukan & $1,72 \mathrm{c}$ & $2,95 \mathrm{c}$ & $3,08 \quad b$ \\
\hline $200 \mathrm{~g}$ trichoderma dalam $8 \mathrm{~kg}$ pukan & $1,55 \mathrm{bc}$ & $2,87 \mathrm{bc}$ & $2,90 \quad \mathrm{a}$ \\
\hline $200 \mathrm{~g}$ trichoderma dalam $12 \mathrm{~kg}$ pukan & $1,42 \mathrm{~b}$ & $2,55 \mathrm{~b}$ & 2,74 a \\
\hline BNJ $(0,05)$ & 0,29 & 0,38 & 0,17 \\
\hline
\end{tabular}

Keterangan : Angka yang diikuti oleh huruf yang sama pada kolom yang sama berbeda tidak nyata pada taraf $\mathrm{a}=5 \%$ (Uji BNJ).

Dari tabel 6, terilihat bahwa ada perbedaan rata-rata panjang daun pada ke 3 umur pengamatan akibat perbedaan dosis campuran trichoderma sp, daun terpanjang dijumpai pada pemberian campuran $200 \mathrm{~g}$ trichoderma sp dengan 4 $\mathrm{kg}$ pupuk kandang $\left(\mathrm{D}_{1}\right)$ dengan nilai berturut-turut $12,68 \mathrm{~cm}, 15,51 \mathrm{~cm}$ dan $19,04 \mathrm{~cm}$ yang berbeda nyata dengan semua perlakuan lainnya, namun tidak berbeda nyata dengan perlakuan $\mathrm{D}_{2}$, kecuali pada umur 90 hari. Sedangkan daun pisang terpendek dijumpai pada perlakuan tanpa pemberian campuran trichoderma $s p \quad\left(\mathrm{D}_{0}\right)$ dengan nilai berturut-turut $9,12 \mathrm{~cm}, 12,16$ dan 15,25 $\mathrm{cm}$ yang berbeda nyata dengan semua perlakuan lainnya kecuali pada umur 90 hari tidak berbeda dengan $D_{2}$ dan $D_{3}$. 
Secara umum pemberian campuran trichoderma sp dengan bahan organik pupuk kandang memperlihatkan pertumbuhan daun yang lebih panjang dibandingkan dengan pisang yang tidak diberikan campuran trichoderma $s p$ dengan bahan organik pupuk kandang, hal ini disebabkan pada pemberian trichoderma $s p$ terdapat koloni sehingga akan menghasilkan miselium yang dapat menekan perkembangan jamur fusarium, hal ini akan menyebabkan perubahan metabolit sekunder, pada perlakuan $\mathrm{D}_{1}$ jumlah trichoderma sp lebih banyak secara otomatis metabolit sekunder yang terbentuk juga lebih banyak, peristiwa ini mengakibatkan ketersedian hasil metabolisme tanman untuk patogen menjadi berkurang disamping itu trichoderma juga dapat bertindak sebagai biodekompuser yang dapat memperbaiki sifat-sifat tanah sehingga dapat menguntungkan bibit. Hal ini sesuai pernyataan (Saraswati dan Sumarno, 2008). bahwa Trichoderma termasuk mikro organisme saprofit yang bertindak sebagai biodekomposer bahan organic yang mengandung serat, lignin, dan senyawa organic yang mengandung nitrogen dan karbon dari bahan organik.

\section{Diameter Batang}

Seperti halnya panjang daun hasil analisis ragam juga menunjukkan bahwa jenis pisang tidak berpengaruh terhadap dimeter batang pada umur 30, 60 dan 90 hari. Hal ini mengindikan bahwa kemampuan menumbuh-kembangkan batang untuk keempat jenis pisang yang ditanam pada lahan petani yang telah terinveksi penyakit layu memperlihatkan diameter batang yang tidak berbeda.
Hasil analisis ragam (Uji $F$ ) menunjukkan bahwa dosis trichoderma sp dengan bahan organik pupk kandang tidak berpengaruh terhadap dimeter batang pisang pada semua umur pengamatan.

Walaupun secara statiska tidak terlihat perbedaan namun secara visual di lapangan terlihat ada perbedaan diameter batang walaupun secara statistika belum memperlihatkan perbedaan yang nyata.

Hal ini dapat digambarkan bahwa laju perkembangan diameter sangat rendah, hal inilah yang mengakibatkan perbedaan satu perlakuan dengan perlakuan lainnya secara statiska belum dapat menunjukkan perbedaan yang nyata.

Umumnya pertumbuhan tanaman dominasi oleh pertumbuhan secara vertikal dibandingkan dengan pertumbuhan lateral.

\section{Pengaruh Interaksi Pemberian Trichoderma Sp dan Beberapa Jenis Pisang}

Hasil penelitian menunjukkan tidak terdapat interaksi yang nyata antara perbedaan jenis pisang dengan dosis pemberian campuran Trichoderma $S p$ dengan pupuk kandangdan terhadap semua peubah pengendalikan penyakit layu fusarium oxysporum di lahan yang terinfeksi. Hal ini membuktikan bahwa, tingkat serangan layu fusarium tersebut tidak tergantung pada jenis pisang, keadaan ini mengindikasikan pula bahwa tidak ada perbedaan toleransi dari jenis pisang dalam melawan serangan penyakit layu fusarium di lahan petani yang telah terinfeksi. 


\section{KESIMPULAN}

Jenis pisang berpengaruh sangat nyata terhadap intensitas serangan penyakit layu fusarium oxysporum . Pisang barangn dan pisang ambon lebih tahan taerhadap serangan pehyakit layu fusarium oxysporum dibanding pisang geupok dan pisang Raja.

Dosis campuran Trichoderma $S p$ dengan bahan organik pupuk kandang berpengaruh sangat nyata terhadap intensitas serangan penyakit layu fusarium oxysporum . Dosis campuran Trichoderma sp $200 \mathrm{~g}$ dengan bahan organik pupuk sebanyak

\section{DAFTAR PUSTAKA}

Harman, G,E. 2000. Changes in perception derived from reasearch on Tricjoderma harzianum. T-22. Journal Plant deases. Vol. 4 (2): 65 - 72ol. 84 (4) : 377 - 392

Nazir, N. 2000. Pisang Budidaya Pengolahan dan Prospek Diserfikasinya. Okada. Yayasan Hutanku : Padang.

Nurbalis dan Martius. 2011. Pemanfaatan baahan organik sebagai pembawa ntuk meningkatkan kepadatan populasi Trichoderma viridae pada rhizosfir pisang dan pengaruhnya terhadap penyakit layu Fusarium. Jurnal. HPT. Trpika. Vol. 11 (2) : 177- 184.

Nurbalis dan Martius. 2009. Pengendalian Fusarium oxysporium sp cubence penyebab penyakit fusarium pada pisang dengan Trichoderma spp indogenus .
$4 \mathrm{~g}$ lebih baik dibandingkan 3 takaran lainnya yaitu campuran Trichoderma sp $200 \mathrm{~g}$ dengan bahan organik pupuk sebanyak $8 \quad \mathrm{~kg}$ dan campuran Trichoderma sp 200 g dengan bahan organik pupuk sebanyak $12 \mathrm{~kg}$ serta perlakua tanpa pemberian campuran Trichoderma $s p$.

Tidak terdapat interaksi yang nyata antara jenis pisang dan pemberian campuran Trichoderma $S p$ dengan bahan organik pupuk kandang terhadap semua peubah pertumbuhan tanaman pisang yang diamati.

Balai penelitian tanam Buahbuaahan. Solok Sumatra Barat.

Purwantisari, S. dan Rini B. H, 2009. Uji Antagonisme Jamur Patogen Phytophthora infestans Penyebab Penyakit Busuk Daun dan Umbi Tanaman Kentang Dengan Menggunakan Trichoderma spp. Isolat Lokal. BIOMA Vol. 11 (1), Hal. 24-32.

Semangun, H. 2004. Penyakitpenyakit Tanaman Hortikultura di Indonesia. Gadjah Mada University Press. Yokyakarta.

Soesanto, L , Rochiadi dan Prihatiningsih, N. 2008. Penekaanan beeberapa microorganisme antagonis terhadap penyakit layu Fusarium gladiol . Jurnal Agrivita. Vol . 30 (1): $75-83$.

Supriyadi dan Satuhu, 2004, Budidaya, pengelolaan dan Prospek Pasar Tanaman Pisang . PT Penebar Swadaya. Jakarta. 
Swastika, W. 2014. Iden tifikasi dan Pengendalian Penyakit Layu Pada Tanaman Pisang di Kota Denpasar. Denpasar. Jurnal DPTPH 1 (1).

Weaver, M. A, Vedenyapina and Kenerly, C.M . 2005. Fitness, persistence and responsifnessof agenetically enginered strain of trichoderma virens in soil mesocoms Alied Soil Ecology. $29: 125-134$. 